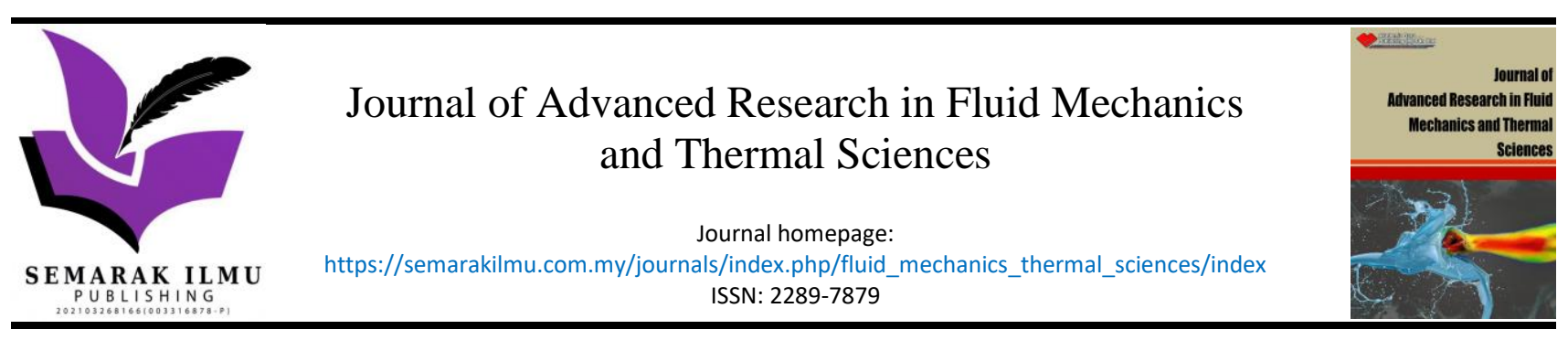

\title{
Evaluation of Heat Transfer Coefficient of Two-Phase Flow Boiling with R290 in Horizontal Mini Channel
}

\author{
Ronald Akbar ${ }^{1}$, Jong Taek Oh², Agus Sunjarianto Pamitran ${ }^{1, *}$ \\ Department of Mechanical Engineering, University of Indonesia, Kampus UI Depok 16424, Indonesia \\ 2 Department of Refrigeration and Air Conditioning Engineering, Chonnam National University, San 96-1, Dunduk-Dong, Yeosu, Chonnam 550- \\ 749, South Korea
}

\section{ARTICLE INFO}

\section{Article history:}

Received 30 April 2021

Received in revised form 15 September 2021

Accepted 27 September 2021

Available online 8 November 2021

Keywords:

Heat transfer coefficient; asymptotic model; R290; two-phase flow boiling; mini channel

\section{ABSTRACT}

\section{Introduction}

Boiling heat transfer in conventional and mini channel tubes is the subject of researchers studying the energy models or processes in heat exchangers. Part of the boiling heat transfer is the heat transfer coefficient, which affects the heat transfer performance itself. Especially in mini channels, the heat transfer coefficient will be higher than in conventional tubes [1]. The results of published research conclude different conclusions about the characteristics of the heat transfer coefficient. Da Silva Lima et al., [2], Ducoulombier et al., [3], and Grauso et al., [4] concluded that the heat transfer coefficient increases with the increase in vapor quality until the flow enters the dry out regime and then decreases sharply in the mist regime that the vapor begins to diffuse in the form of bubbles, reducing the heat transfer. Meanwhile, Hamdar et al., [5], Saisorn et al., [6], and Anwar [7] stated

\footnotetext{
* Corresponding author.

E-mail address: pamitran@eng.ui.ac.id

https://doi.org/10.37934/arfmts.88.3.8895
} 
that the heat transfer coefficient is independent of the vapor quality. Then, Shiferaw et al., [8] showed that the heat transfer coefficient's value peaks at the lower vapor quality, usually at the nucleate boiling, and decreases with the increase of vapor quality.

Many environmentally friendly refrigerants are used to replace refrigerants with high ODP (Ozone Depletion Potential) and GWP (Global Warming Potential), which can damage the atmosphere. R290 or propane is an environmentally friendly refrigerant and a natural refrigerant with zero ODP and GWP [9]. R290 will not damage the atmosphere, environment and has a higher cooling capacity than R22 [10]. Padalkar et al., [11] stated that R290 can improve the efficiency and heat transfer quality. The asymptotic model is one of the correlation approaches of heat transfer coefficient. Liu and Winterton [12] and Steiner and Taborek [13] pointed out that the asymptotic model combines nucleate and convective boiling mechanisms. The nucleate boiling mechanism occurs when the heated tube's temperature is higher than the fluid's saturation temperature. Meanwhile, convective boiling usually occurs in the annular regime, characterized by forming a liquid layer on the edge of the tube, in which vapor flowing in the core [14]. With the increase of vapor, the convective boiling mechanism will slowly suppress the nucleate boiling and form a complete boiling flow phenomenon. This asymptotic model correlates as in Eq. (1) [15].

$h_{t p}=\left[\left(h_{n b}\right)^{n}+\left(h_{c b}\right)^{n}\right]^{\frac{1}{n}}$

Where $h_{n b}$ is the heat transfer coefficient of nucleate boiling in $\mathrm{kW} / \mathrm{m}^{2}{ }^{\circ} \mathrm{C}, h_{c b}$ is the heat transfer coefficient of convective boiling in $\mathrm{kW} / \mathrm{m}^{2}{ }^{\circ} \mathrm{C}$, and the variable $n$ is the ratio between heat flux and heat transfer coefficient.

This research aims determine the characteristics of the heat transfer coefficient of refrigerant R290 from the available data. Only a few researchers use mini channel tubes and R290 as their working fluids. The various asymptotic model correlations are then used to predict the data to know which the best correlation can predict the experimental heat transfer coefficient data. The results are expected to be a reference for designing a heat exchanger or further research.

\section{Methodology}

\subsection{Experimental Set Up}

In this study, authors used the heat transfer coefficient experimental data derived from the research conducted by Pamitran et al., [16]. The experimental setup is shown in Figure 1. The components consisted of a condenser, cooling system, liquid receiver, refrigerant pump, Coriolis mass flow meter, preheater, and a test section. The needle valve controlled the refrigerant's mass flow rate, and it was measured by a Coriolis mass flow meter. A preheater was installed to control the refrigerant's vapor quality by heating it before entering the test section. The test section was a tube made of stainless steel, with a smooth surface, a diameter of $3 \mathrm{~mm}$, and a length of $2 \mathrm{~m}$ insulated to minimize heat loss to the environment. The mass flux varied from $50 \mathrm{~kg} / \mathrm{m}^{2} \mathrm{~s}-180 \mathrm{~kg} / \mathrm{m}^{2} \mathrm{~s}$ and 5 $\mathrm{kW} / \mathrm{m}^{2}-20 \mathrm{~kW} / \mathrm{m}^{2}$ of heat flux. The refrigerant's saturation pressure was used to determine the saturation temperature, measured using a pressure gauge at the inlet and outlet of the test section. The sight glass was installed at the inlet and outlet for flow visualization. 


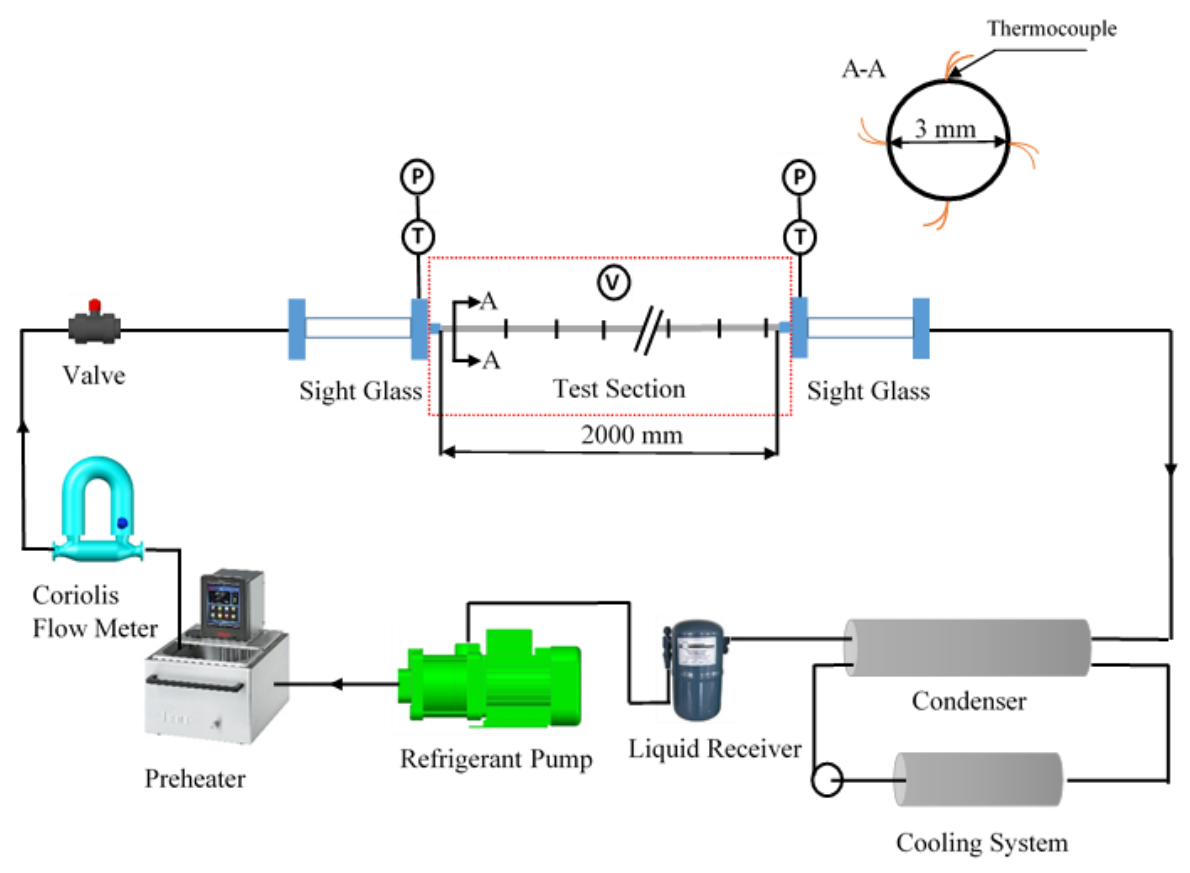

Fig. 1. Experimental set up

\subsection{Data Reduction}

The saturation pressure measured at the inlet and outlet of the test section is used to obtain the refrigerant's physical properties. The vapor quality in the test section is calculated using Eq. (2).

$x=\frac{i-i_{f}}{i_{f g}}$

Where $i$ is the enthalpy, $f$ and $g$ is the condition of liquid and vapor at the saturation temperature, respectively. The subcooled length $Z_{s c}$ is used to determine the saturation's starting point, calculated using Eq. (3).

$Z_{s c}=L \frac{i_{f}-i_{f, i n}}{(Q / W)}$

Where $L$ is the length of the tube, $Q$ is the electricity power, and $W$ is the mass flow rate. The experimental heat transfer coefficient $h$ along the test section can be obtained using Eq. (4).

$h=\frac{q}{T_{w i}-T_{s a t}}$

Where $q$ is the heat flux, $T$ is the temperature, $w i$ is the inner wall of the test section, and sat is the saturation condition.

\subsection{Correlation Analysis}

Several correlations from the other five authors will be used to predict the experimental heat transfer coefficient data. All correlations used are the modification and adjusted from their research data and based on the asymptotic model. The value of the variable $n$ is different for each author. Aizuddin et al., [10], Kim and Mudawar [18], Sempértegui-Tapia and Ribatski [19], and Zou et al., [20] 
used $n=2$ in their correlation. Then, Turgut and Asker [17] used $n=3$ in their asymptotic model correlation.

The research conditions and refrigerants used by each author are also different. The mass flux varied from $19 \mathrm{~kg} / \mathrm{m}^{2} \mathrm{~s}$ to $1608 \mathrm{~kg} / \mathrm{m}^{2} \mathrm{~s}$, the heat flux from $0.5 \mathrm{~kW} / \mathrm{m}^{2}$ to $145 \mathrm{~kW} / \mathrm{m}^{2}$, and the refrigerants used varied from R290 to $\mathrm{CO}_{2}$. The test section used varied from $0.19 \mathrm{~mm}$ to $9.52 \mathrm{~mm}$, which is confirmed in the range of microchannels to conventional channels tube. Table 1 shows the correlation of the heat transfer coefficients used in this study.

Table 1

The heat transfer coefficient correlations used in this study

\begin{tabular}{|c|c|c|}
\hline Authors & Equations & Conditions \\
\hline $\begin{array}{l}\text { Aizuddin et } \\
\text { al., [10] }\end{array}$ & $\begin{aligned} h_{t p}= & {\left[\left(h_{n b}\right)^{2}+\left(h_{c b}\right)^{2}\right]^{\frac{1}{2}} } \\
h_{n b}= & {\left[\left(a_{1}\right)\left(B o \frac{P_{H}}{P_{F}}\right)^{\left(a_{2}\right)} P_{r}^{\left(a_{3}\right)}(1-x)^{\left(a_{4}\right)}\right]\left(0.023 R e_{f}^{0.8} P r_{f}^{0.4} \frac{k_{f}}{D_{h}}\right) } \\
h_{c b}= & {\left[\left(a_{5}\right)\left(B o \frac{P_{H}}{P_{F}}\right)^{\left(a_{6}\right)} W e_{f o}^{\left(a_{7}\right)}+\left(a_{8}\right)\left(\frac{1}{X_{t t}}\right)^{\left(a_{9}\right)}\left(\frac{\rho_{g}}{\rho_{f}}\right)^{\left(a_{10}\right)}\right] } \\
& \left(0.023 R e_{f}^{0.8} P r_{f}^{0.4} \frac{k_{f}}{D_{h}}\right)\end{aligned}$ & $\begin{array}{l}\text { R290 } \\
D: 3 \mathrm{~mm} \\
\mathrm{G}: 100-200 \mathrm{~kg} / \mathrm{m}^{2} \mathrm{~s} \\
\mathrm{q}: 5-15 \mathrm{~kW} / \mathrm{m}^{2} \\
\mathrm{~T}_{\text {sat }}: 10^{\circ} \mathrm{C}\end{array}$ \\
\hline $\begin{array}{l}\text { Turgut and } \\
\text { Asker [17] }\end{array}$ & $\begin{array}{l}h_{t p}=\left[\left(h_{n b}\right)^{3}+\left(h_{c b}\right)^{3}\right]^{\frac{1}{3}} \\
h_{c b}=\left(0.023 \operatorname{Re}_{f}^{0.8} \operatorname{Pr}_{f}^{0.4} \frac{k_{f}}{D_{h}}\right)\left(A_{1}\left(\frac{1}{C o}\right)^{A_{2}}\right) \\
h_{n b}=A_{3} h_{\text {Cooper }}^{A_{4}} P_{r}^{A_{5}}(1-x)^{A_{6}} \\
h_{\text {Cooper }}=55 P_{r}^{0.12-0.087 \ln \varepsilon}\left(-0.4343 \ln P_{r}\right)^{-0.55} M^{-0.5} q^{0.67}\end{array}$ & $\begin{array}{l}\mathrm{R} 744\left(\mathrm{CO}_{2}\right) \\
\mathrm{D}_{\mathrm{h}}: 0.529-9.52 \mathrm{~mm} \\
\mathrm{G}: 100-1400 \mathrm{~kg} / \mathrm{m}^{2} \mathrm{~s} \\
\mathrm{q}: 5-45 \mathrm{~kW} / \mathrm{m}^{2} \\
\mathrm{~T}_{\text {sat }}:-35-20^{\circ} \mathrm{C}\end{array}$ \\
\hline $\begin{array}{l}\text { Kim and } \\
\text { Mudawar [18] }\end{array}$ & $\begin{aligned} h_{t p}= & {\left[\left(h_{n b}\right)^{2}+\left(h_{c b}\right)^{2}\right]^{\frac{1}{2}} } \\
h_{n b}= & {\left[2345\left(B o \frac{P_{H}}{P_{F}}\right)^{0.70} P_{r}^{0.38}(1-x)^{-0.51}\right]\left(0.023 \operatorname{Re}_{f}^{0.8} \operatorname{Pr}_{f}^{0.4} \frac{k_{f}}{D_{h}}\right) } \\
h_{c b}= & {\left[5.2\left(B o \frac{P_{H}}{P_{F}}\right)^{0.08} W e_{f o}^{-0.54}+3.5\left(\frac{1}{X_{t t}}\right)^{0.94}\left(\frac{\rho_{g}}{\rho_{f}}\right)^{0.25}\right] } \\
& \left(0.023 \operatorname{Re}_{f}^{0.8} \operatorname{Pr}_{f}^{0.4} \frac{k_{f}}{D_{h}}\right)\end{aligned}$ & $\begin{array}{l}18 \text { different refrigerant } \\
D_{h}: 0.19-6.5 \mathrm{~mm} \\
\mathrm{G}: 19-1608 \mathrm{~kg} / \mathrm{m}^{2} \mathrm{~s} \\
\mathrm{q}: 0.5-5 \mathrm{~kW} / \mathrm{m}^{2}\end{array}$ \\
\hline $\begin{array}{l}\text { Sempértegui- } \\
\text { Tapia and } \\
\text { Ribatski [19] }\end{array}$ & $\begin{array}{l}h_{t p}=\left[\left(S . h_{n b}\right)^{2}+\left(F \cdot h_{c b}\right)^{2}\right]^{\frac{1}{2}} \\
h_{n b}=207 \frac{k_{f}}{D}\left(\frac{q D}{k_{f} T_{s a t}}\right)^{0.745}\left(\frac{\rho_{g}}{\rho_{f}}\right)^{0.581}\left(\frac{\mu_{f}}{\rho_{f}} \frac{\rho_{f} c_{p f}}{k_{f}}\right)^{0.533} \\
h_{c b}=\left(0.023 \frac{k_{f}}{D} R e_{f}^{0.8} P r_{f}^{\frac{1}{3}}\right) \\
S=\frac{c_{s, 1} B d^{c_{s, 2}}}{1+c_{s, 3}\left(10^{-4} R e_{f} F^{1.25}\right)^{c_{S, 4}}} \quad F=1+\frac{c_{f, 1} X_{t t}{ }^{c} f, 2}{\left(1+W e_{u g}^{c_{f, 3}}\right)}\end{array}$ & $\begin{array}{l}\text { R134a, R1234ze(E), } \\
\text { R1234yf, and R600a } \\
D: 1-2.6 \mathrm{~mm} \\
\mathrm{G}: 200-800 \mathrm{~kg} / \mathrm{m}^{2} \mathrm{~s} \\
\mathrm{q}: 15-145 \mathrm{~kW} / \mathrm{m}^{2} \\
\mathrm{~T}_{\text {sat }}:-31-41^{\circ} \mathrm{C}\end{array}$ \\
\hline Zou et al., [20] & $\begin{array}{l}h_{t p}=\left[\left(K . S . h_{n b}\right)^{2}+\left(F . h_{c b}\right)^{2}\right]^{\frac{1}{2}} \\
h_{n b}=55 P_{r}^{0.12}\left(-\ln P_{r}\right)^{-0.55} M^{-0.5} q^{0.67} \\
h_{c b}=\left(0.023 R e_{f}^{0.8} P r_{f}^{0.4} \frac{k_{f}}{D_{h}}\right) \\
S=\left(1+0.55 F^{0.1} \operatorname{Re}_{f}^{0.16}\right)^{-1} \\
F=\left[1+x_{a v e} P r_{f}\left(\frac{\rho_{f}}{\rho_{g}}-1\right)\right]^{0.35} \\
K=\frac{h_{m}}{h_{i}}=\frac{1}{1+\frac{\Delta T_{b p}}{\Delta T_{i d}}|y-x|^{C_{1}}\left(\frac{P}{10^{5}}\right)^{C_{2}}\left[1+C_{3} \exp \left(-\frac{q}{3 \times 10^{5}}\right)\right]}\end{array}$ & $\begin{array}{l}\text { Blended of R170 and R290 } \\
D_{h}: 8 \mathrm{~mm} \\
\mathrm{G}: 63.6-102.5 \mathrm{~kg} / \mathrm{m}^{2} \mathrm{~s} \\
\mathrm{q}: 13.1-65.5 \mathrm{~kW} / \mathrm{m}^{2}\end{array}$ \\
\hline
\end{tabular}

\section{Results and Discussion}

The experimental data were carried out under the mass flux from $50 \mathrm{~kg} / \mathrm{m}^{2} \mathrm{~s}$ to $180 \mathrm{~kg} / \mathrm{m}^{2} \mathrm{~s}$ and heat flux from $5 \mathrm{~kW} / \mathrm{m}^{2}$ to $20 \mathrm{~kW} / \mathrm{m}^{2}$. According to the experimental data, the heat transfer 
coefficient is influenced by mass flux and heat flux. Figure 2 shows the effect of mass flux on the heat transfer coefficient experimental data with $15 \mathrm{~kW} / \mathrm{m}^{2}$ of heat flux.

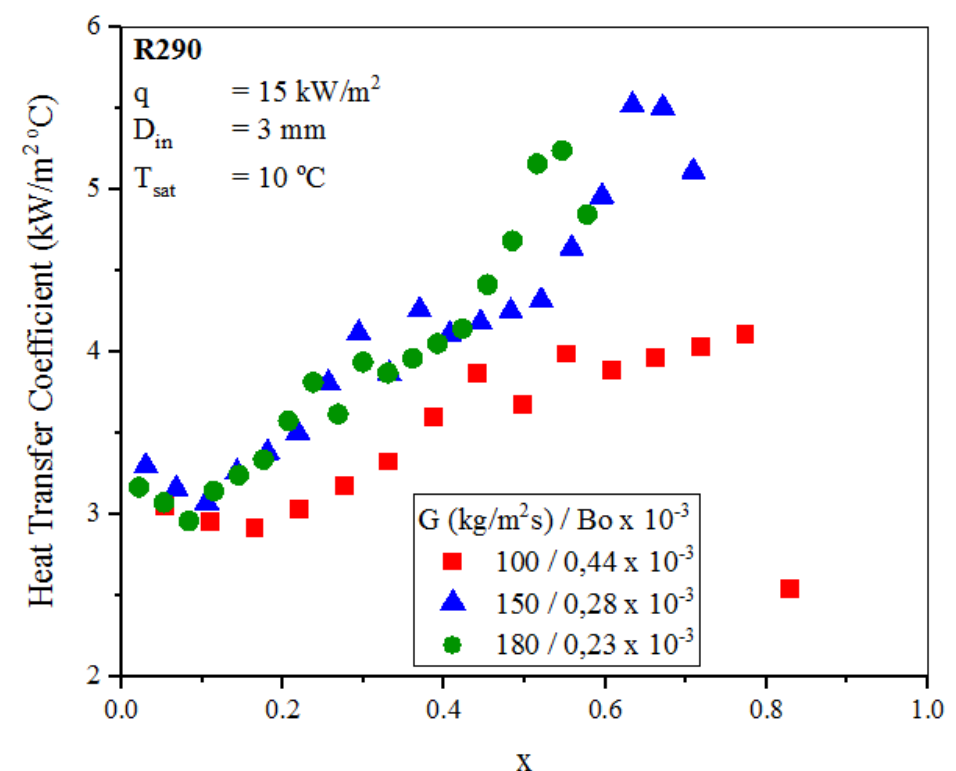

Fig. 2. The effect of mass flux on the heat transfer coefficient

It can be seen that if the value of mass flux is greater, the heat transfer coefficient will reach a higher value. However, at the low vapor quality, the effect of mass flux is not too significant. That is because the nucleate boiling mechanism dominates the heat transfer at the low vapor quality, that often occurs in mini channel tubes [21]. Then the domination of the nucleate boiling mechanism can also be seen from the value of the Boiling Number. Here, the smaller the Boiling Number, makes the higher value of the heat transfer coefficient. That is under what was stated by Kanizawa et al., [22].

Figure 3 shows the effect of heat flux on the heat transfer coefficient with $100 \mathrm{~kg} / \mathrm{m}^{2} \mathrm{~s}$ of mass flux. In Figure 3, it can be seen that if the value of heat flux is greater, the heat transfer coefficient will reach a higher value. However, the effect of heat flux is only seen significantly at the low vapor quality or at nucleate boiling dominated mechanism. Then, the effect of heat flux will be more significant as the Boiling Number increases, that is under what was stated by Kanizawa et al., [22].

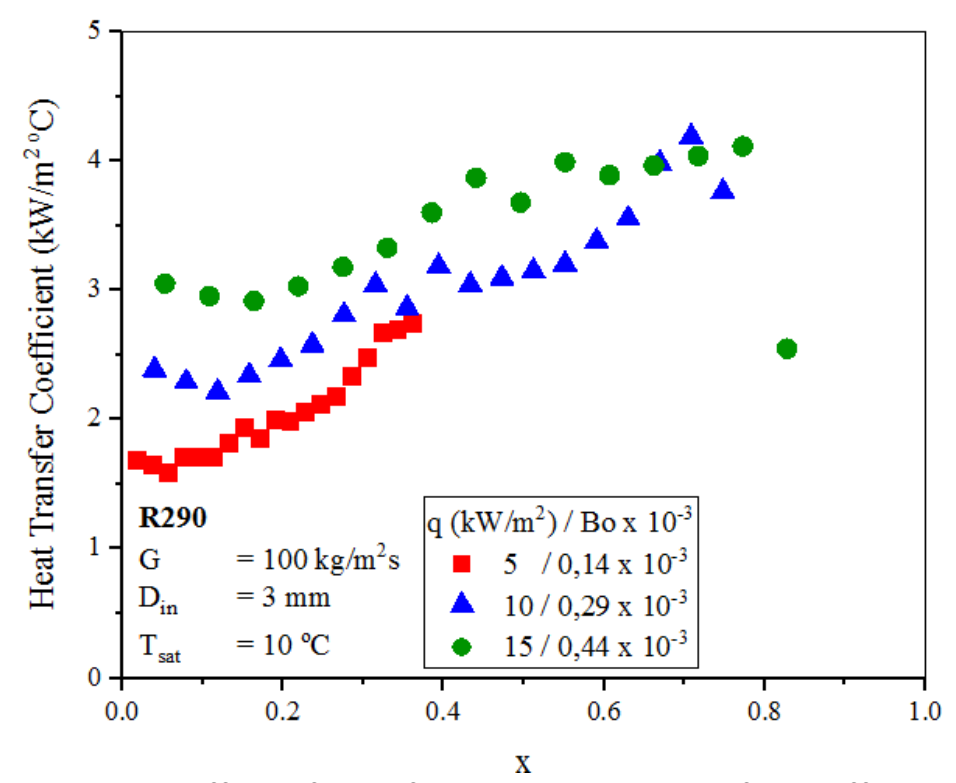

Fig. 3. The effect of heat flux on the heat transfer coefficient 
The five correlations of the asymptotic model are used to find the best predict correlation with the current heat transfer coefficient data. Table 2 shows the deviation of five asymptotic model correlations and Figure 4 shows the selected result between the heat transfer coefficient with existing correlation.

Table 2

Deviation of The Heat Transfer Coefficient Correlations

\begin{tabular}{llllll}
\hline $\begin{array}{l}\text { Deviation } \\
\text { (\%) }\end{array}$ & $\begin{array}{l}\text { Aizuddin et al., } \\
{[10]}\end{array}$ & $\begin{array}{l}\text { Sempértegui-Tapia } \\
\text { and Ribatski [19] }\end{array}$ & $\begin{array}{l}\text { Kim and Mudawar } \\
{[18]}\end{array}$ & Zou et al., [20] & $\begin{array}{l}\text { Turgut and Asker } \\
{[17]}\end{array}$ \\
\cline { 2 - 6 } & 11.6 & 31.53 & 39.68 & 42.14 & 157.58 \\
\hline
\end{tabular}
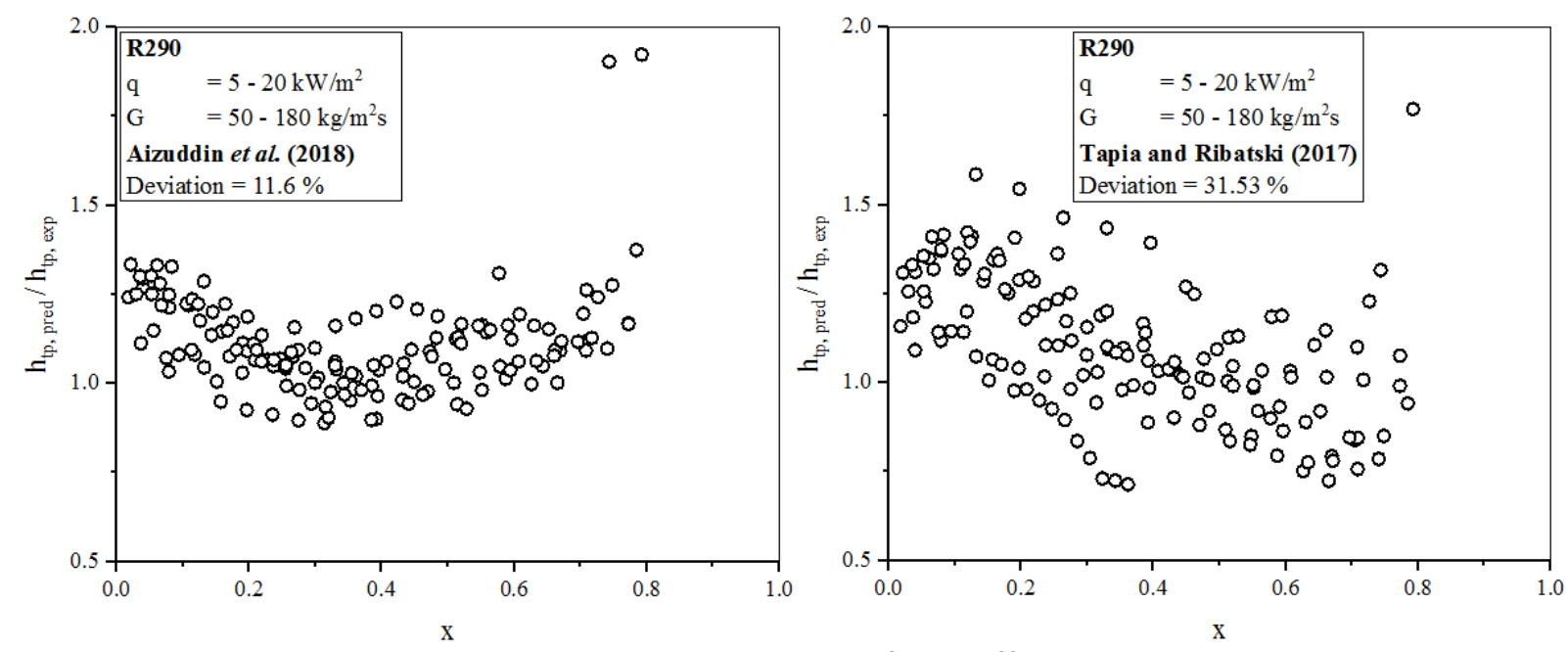

Fig. 4. The selected Result between The Heat Transfer Coefficient with Existing Correlation

Overall, Aizuddin et al.,'s [10] correlation gave the best prediction of all five. Aizuddin et al.,'s [10] correlation was developed with R290 and based on the condition of mass flux 150 and $200 \mathrm{~kg} / \mathrm{m}^{2} \mathrm{~s}$ with heat flux $15 \mathrm{~kW} / \mathrm{m}^{2}$ and mass flux $100 \mathrm{~kg} / \mathrm{m}^{2} \mathrm{~s}$ with heat flux 5 and $10 \mathrm{~kW} / \mathrm{m}^{2}$. So, the correlation was very good at predicting the heat transfer coefficient in this study. Sempértegui-Tapia and Ribatski's [19] correlation which is the second-best correlation developed with three different refrigerants and based on a wider condition range than the experimental data in this study. Therefore, the deviation was quite significant compared to the Aizuddin et al.,'s [10] correlation. Turgut and Asker's [17] correlation was considered less accurate in predicting the current heat transfer coefficient data because of the used of $\mathrm{CO}_{2}$ as the refrigerant. Turgut and Asker stated that the characteristic of $\mathrm{CO}_{2}$ could not be clearly identified due to the different thermal behavior from other refrigerants.

\section{Conclusions}

R290 or propane is a natural refrigerant with zero ODP and GWP, which does not damage the atmosphere and has high efficiency and heat transfer performance. The experimental data shows that the heat transfer coefficient is influenced by mass flux and heat flux. The effect of mass flux is significant at a higher vapor quality. On the other hand, the effect of heat flux is significant at a lower vapor quality.

All of the predicted heat transfer coefficient with asymptotic model correlations used in this study have a good and similar result to the experimental data. 


\section{Acknowledgement}

This research was funded by a grant from Universitas Indonesia, PUTI Q3 2020, No. BA1733/UN2.RST/PPM.00.03.01/2020

\section{References}

[1] Novianto, Sentot, Raldi Artono Koestoer, and Agus Sunjarianto Pamitran. "Analysis of Temperature and Heat Measurement on Twophase Flow Nucleate Boiling with R-290 in Microchannel." Journal of Advanced Research in Fluid Mechanics and Thermal Sciences 54, no. 1 (2019): 87-94.

[2] da Silva Lima, Ricardo J., Jesús Moreno Quibén, and John R. Thome. "Flow boiling in horizontal smooth tubes: New heat transfer results for R-134a at three saturation temperatures." Applied Thermal Engineering 29, no. 7 (2009): 1289-1298. https://doi.org/10.1016/i.applthermaleng.2008.06.021

[3] Ducoulombier, Maxime, Stéphane Colasson, Jocelyn Bonjour, and Philippe Haberschill. "Carbon dioxide flow boiling in a single microchannel-Part II: Heat transfer." Experimental Thermal and Fluid Science 35, no. 4 (2011): 597-611. https://doi.org/10.1016/i.expthermflusci.2010.11.014

[4] Grauso, S., R. Mastrullo, A. W. Mauro, J. R. Thome, and Giuseppe Peter Vanoli. "Flow pattern map, heat transfer and pressure drops during evaporation of R-1234ze (E) and R134a in a horizontal, circular smooth tube: Experiments and assessment of predictive methods." International Journal of Refrigeration 36, no. 2 (2013): 478491. https://doi.org/10.1016/i.ijrefrig.2012.07.016

[5] Hamdar, Marian, Assaad Zoughaib, and Denis Clodic. "Flow boiling heat transfer and pressure drop of pure HFC$152 a$ in a horizontal mini-channel." International Journal of Refrigeration 33, no. 3 (2010): 566-577. https://doi.org/10.1016/i.ijrefrig.2009.12.006

[6] Saisorn, Sira, Jatuporn Kaew-On, and Somchai Wongwises. "Two-phase flow of R-134a refrigerant during flow boiling through a horizontal circular mini-channel." Experimental Thermal and Fluid Science 35, no. 6 (2011): 887895. https://doi.org/10.1016/i.expthermflusci.2011.01.008

[7] Anwar, Zahid. "Evaporative heat transfer with R134a in a vertical minichannel." Pakistan Journal of Engineering and Applied Sciences 13, no. 2 (2013): 101-109.

[8] Shiferaw, D., X. Huo, T. G. Karayiannis, and D. B. R. Kenning. "Examination of heat transfer correlations and a model for flow boiling of R134a in small diameter tubes." International Journal of Heat and Mass Transfer 50, no. 25-26 (2007): 5177-5193. https://doi.org/10.1016/j.ijheatmasstransfer.2007.07.002

[9] La Rocca, Vincenzo, and Giuseppe Panno. "Experimental performance evaluation of a vapour compression refrigerating plant when replacing R22 with alternative refrigerants." Applied Energy 88, no. 8 (2011): 2809-2815. https://doi.org/10.1016/j.apenergy.2011.01.051

[10] Aizuddin, Nik, Normah Mohd-Ghazali, and Yushazaziah Mohd-Yunos. "Analysis of Convective Boiling Heat Transfer Coefficient Correlation of R290." Jurnal Mekanikal 41 (2018): 39-44.

[11] Padalkar, Atul S., Kundlik V. Mali, and Sukumar Devotta. "Simulated and experimental performance of split packaged air conditioner using refrigerant HC-290 as a substitute for HCFC-22." Applied Thermal Engineering 62, no. 1 (2014): 277-284. https://doi.org/10.1016/j.applthermaleng.2013.09.017

[12] Liu, Z., and R. H. S. Winterton. "A general correlation for saturated and subcooled flow boiling in tubes and annuli, based on a nucleate pool boiling equation." International Journal of Heat and Mass Transfer 34, no. 11 (1991): 2759-2766. https://doi.org/10.1016/0017-9310(91)90234-6

[13] Steiner, Dieter, and Jerry Taborek. "Flow boiling heat transfer in vertical tubes correlated by an asymptotic model." Heat Transfer Engineering 13, no. 2 (1992): 43-69. https://doi.org/10.1080/01457639208939774

[14] Collier, John G., and John R. Thome. Convective boiling and condensation. Clarendon Press, 1994.

[15] Ghiaasiaan, S. Mostafa. Two-phase flow, boiling, and condensation: in conventional and miniature systems. Cambridge University Press, 2007. https://doi.org/10.1017/CBO9780511619410

[16] Pamitran, Agus Sunjarianto, Kwang-Il Choi, and Jong-Taek Oh. "Evaporation heat transfer coefficient in single circular small tubes for flow natural refrigerants of $\mathrm{C} 3 \mathrm{H} 8, \mathrm{NH} 3$, and $\mathrm{CO} 2 . "$ International Journal of Multiphase Flow 37, no. 7 (2011): 794-801. https://doi.org/10.1016/i.ijmultiphaseflow.2011.02.005

[17] Turgut, Oguz Emrah, and Mustafa Asker. "Saturated flow boiling heat transfer correlation for carbon dioxide for horizontal smooth tubes." Heat and Mass Transfer 53, no. 6 (2017): 2165-2185. https://doi.org/10.1007/s00231017-1975-x

[18] Kim, Sung-Min, and Issam Mudawar. "Universal approach to predicting saturated flow boiling heat transfer in mini/micro-channels-Part II. Two-phase heat transfer coefficient." International Journal of Heat and Mass Transfer 64 (2013): 1239-1256. https://doi.org/10.1016/j.ijheatmasstransfer.2013.04.014 
[19] Sempértegui-Tapia, Daniel Felipe, and Gherhardt Ribatski. "Flow boiling heat transfer of R134a and low GWP refrigerants in a horizontal micro-scale channel." International Journal of Heat and Mass Transfer 108 (2017): 24172432. https://doi.org/10.1016/j.ijheatmasstransfer.2017.01.036

[20] Zou, Xin, M. Q. Gong, G. F. Chen, Z. H. Sun, Y. Zhang, and J. F. Wu. "Experimental study on saturated flow boiling heat transfer of R170/R290 mixtures in a horizontal tube." International Journal of Refrigeration 33, no. 2 (2010): 371-380. https://doi.org/10.1016/i.jirefrig.2009.10.013

[21] Pamitran, Agus Sunjarianto, Kwang-II Choi, Jong-Taek Oh, and Ki-Won Park. "Two-phase flow heat transfer of propane vaporization in horizontal minichannels." Journal of Mechanical Science and Technology 23, no. 3 (2009): 599-606. https://doi.org/10.1007/s12206-008-0913-8

[22] Kanizawa, Fabio Toshio, Cristiano Bigonha Tibiriçá, and Gherhardt Ribatski. "Heat transfer during convective boiling inside microchannels." International Journal of Heat and Mass Transfer 93 (2016): 566-583. https://doi.org/10.1016/i.ijheatmasstransfer.2015.09.083 